Hysteresis in Unemployment by

Olivier J. Blanchard

Number 430

September 1986 
Digitized by the Internet Archive in 2011 with funding from MIT Libraries 


\section{Hysteresis in Unemployment}

Olivier J. Blanchard and Lawrence H. Summers*

* MIT and NBER, and Harvard and NBER respectively

We are grateful to Niels Gottfries for comments on an earlier draft of this paper. 



\section{Abstract}

The racent European experience of inigh persistent unemployment has led to ine development of theories of unemployment hysteresis embodying the idea that the equilibrium unemployment rate depends on the history of the actual unemployment rate. This paper summarizes two directions of research on hysteresis that appear especially promising. Membership theories are based on the distinction between insiders and outsiders and explore the idea that wage setting is largely determined by firms' incumbent workers rather than by the unempioyed. Duration theories explore the idea that the long term unemployed exert much less downwards pressure on wages than do the short term unemployed.

Olivier J. Elanchard

Department of Economics, MIT

Camizidge Mt. 02139

$(617)-253-8 \varepsilon \subseteq 1$
Lawrence H. Summers Department of Economics Harvard University Cambridge MA. 02138 (617) -495-2447 

Standard macroeconomic models make a sharp distinction between

equilibrium and actual unemployment. Equilibrium unemployment is determined by labor market institutions, moves slowly and is unaffected by actual

unemployment. Unexpected movements in demand and supply lead to deviations of actual unemployment from equilibrium; these deviations in turn trigger changes in the rate of inflation, which lead eventually to a return to equilibrium unemployment.

The European experience of the last ten years, like the Depression of the $1930^{\prime}$ s, strongly suggests that the standard model may not capture important aspects of reality. As actual unemployment has gone up, equilibrium unemployment, as estimated from Phillips curve relations, has risen in tandem. Today, unemployment in the EEC exceeds 118. But, were it not for the fall in the price of oil and the depreciation of the dollar, inflation would be roughly constant. Put another way, the actual level of unemployment appears to be the equilibrium level. While this could as a matter of logic be due to shocks increasing both the equilibrium and the actual rates, empirical attempts to identify such shocks have failed. Lower productivity growth and higher oil prices may help explain the $70^{\prime}$ s, but there are very few identifiable adverse shocks which can explain a doubling of equilibrium unemployment in the 80's.

The recent European experience has led to the development of alternative theories of unemployment embodying the idea that the equilibrium unemployment rate depends on the history of the actual unemployment rate. Such theories may be labelled hysteresis theories after the term in the physical sciences referring to situations where equilibrium is path-dependent. ${ }^{1}$ Two directions

I Strictly speaking, the word hysteresis should be used only in the case where there is path dependence of steady state equilibrium unemployment. We shall use it more loosely to denote cases where actual unemployment affects equilibrium unemployment for a long time. The idea that the macroeconomy may exhibit 

of research on hysteresis appear very promising. Both focus on the labor market and the relation of unemployment to wage setting. First membership theories are based on the distinction between insiders and outsiders and explore the idea that wage setting is largely determined by firms' incumbent workers rather than by the unemployed. Second, duration theories are based on the distinction between short term and long term unemployed and explore the idea that the long term unemployed exert little pressure on wage setting. This paper shows, using a simple macroeconomic model, how these theories can, singly or together, explain high persistent unemployment.

In what follows, we focus on wage bargaining. To do so, we make the conventional -but not uncontroversial-assumption that wage bargaining determines the nominal wage, with firms being free to choose employment ex post. Therefore we first specify the demand for labor. We then consider tha implications of alternative wage setting mechanisms for the persistence of unemployment. We start with the pure insider case, in which the wage is set by insiders, with no pressure from outsiders on wage setting and then consider the more general case where outsiders exert some pressure. Finally, we study the case where not all outsiders exert the same pressure on wage bargains.

\section{The derived demand for labor.}

There are many firms in the economy. The demand facing each firm is a function of aggregate demand, which itself depends on real money ba'ances, and

hysteresis is not new. Hysteresis effects were for example discussed in Phelps (1972). An analysis of their implications for policy may be fourd in Sachs (1985). Other recent papers examining hysteresis explanations for the European experience are discussed below. 

iss own price relative to the overall price level. For simplicity, we assume that the only potential source of fluctuations in the economy is nominal money, which, if prices do not adjust, affects aggregate demand and employment. All the variailes in what follows are in logarithms and we ignore all unimportant constants. Formally, the demand facing firm $i$ is given by :

(1) $y_{i}=(m-p)-a\left(p_{i}-p\right) ; a>1$

where $y_{i}, p_{i}$ are the firm's output and nominal price, and $m$ and $p$ are nominal money and the price level.

Each $f_{i r m}$ operates under constant returns to scale, so that $y_{i}=n_{i}$, where $n_{i}$ is employment in firm $i$; given constant marginal cost and constant elasticity of demand, profit maximisation implies $p_{i}-w_{i}$, where $w_{i}$ is the nominal wage paid by firm $i$. Using these relations, and noting that $p=w$, where $w$ is the aggregate nominal wage index, we obtain a derived demand for labor by firm i :

(2) $n_{i}=(m-w)-a\left(w_{i}-\dot{w}\right)$

Employwent in each firm depends on real money balances in wage units, and on the relative wage paid by the firm. The determination of employment along this cerived demand curve depends on the process of wage setting, to which we now turn. In all cases, we assume that nominal wage bargains are set before nominal money is known.

\section{Wage sett:ng in a pure insider model ${ }^{2}$}

2 The idea tinat wages are the result of a bargain between insiders and the firm has been expiored in a series of contributions by Lindbeck and Snower ((1985) for example). Gregury (1986), looking at Australia, was the first to argue that insicer considerations could explain high sustained unemployment. The implications for eggregate unemployment have also been examined by Lindbeck and Snower (1984), Blanchard and Summers (1986a) and Gottfries ard Horn (1986). The anslysis of this section relies heavily on blanchard and Summers. 

In the sinplest insider model, there is associated with each firm i a group of workers, the insioers or incumbents, with membership $n_{i}$. They are the or: ly ones whose interests are represented in wage bargaining. Furthermore, they have priority in employment ; only when all insiders are employed can the. firm hire outsiders.

The assumption that wages are set primarily with regard to the interests of incumbent workers is easily justified. In unionized settings, wage decisiors whether made by median voters or senior workers are likely to give little weight to the interests of unemployed members and less to the interests of non-members. Ir non-union settings incumbent workers are likely to have bargaining power because of the fixed costs of hiring a new worker, and because of they can threaten to withhold effort. The differontial importance of . incumbent workers in wage setting decisions is exemplified by the reluctance of Lnions to accept two tier contracts. Their reluctance stems from fears that eventially wage decisions will come to be made not in the interests of current mexiers but irstear in the interests of new lower tier workers.

Assumirg that, in each firm, the g:oup of insiders is sufficiently strong to set the wage unilate:ally and sets it so as to make expected employment be equal to the size of the membership we have: ${ }^{3}$

(3) $\operatorname{En}_{i}-=_{i} *$

This in turn implies, using (2), that the nominal wage satisfies Em-Ew-

3 Derivation from first principles yields in general a more complex outcome. In Blanchard and Summers, for example, insiders set the wage so as to make the prosability of employment equal to some constant. If insiders set the F: obability sufficiently high, this implies that expected employment exceeds misership. stchough, in average, some outsiders are hired, they are hired to decrease the ris: to insiders of being laid off. 

$a\left(w_{i}-E w\right)=n_{i} *$. Given that all firms and groups of workers are the same, ard that the only shocks are aggregate nominal shocks, all groups of workers choose the same nominal wage. Thus, $w_{i}=w=E w$. Replacing in (2), and dropping the index $i$ as employment is the same in all firms

$$
n=n *+(m-E m)
$$

Employment is equal to membership plus a disturbance, eçual to the. unanticipated movement in nominal money.

The crucial issue in the context of this model is how membership is determined. If we think of the group of workers as a union, who does the union represent when it sets the wage? Almost surely, the union will care more about the currently employed than about others. If, for example, it cares only about the workers employed at the time of bargaining, $n_{i}$ is equal to $n_{i}(-1)$. Substituting in the previous equation yields:

(5) $n=n(-1)+(m-E m)$

The implications of such a membership rule for employment are drastic : employment follows a random walk, with the innovations being die to unexpected movements in aggregate demand. For a given labor force, equilibrium unemployment is equal to last period's value of actual unemployment in the standard terminology. The economy shows no tendency to return to any fixed equilibrium value. The mechanism behind this result is transparent : after an adverse shock which reduces employment, workers who are still employed have no desire to cut the nominal wage so as to increase employment. After a favorable shock which increases employment, some outsiders are now employed and will have no desire to increase wages and to price themselves out of employment..

The connection between membership and employment is probably not as tight as we have portrayed it. Recently laid off workers may well still be considered 

insiders ; recently hired outsiders may well not be considered insiders. New entrants to the labor force but with family ties to insiders may be treated as insiders. If for example it takes a few periods of unemployment to lose insider status, and a few periods of employment to acquire it, the dynamics of employment are more complex, and in an interesting way. In this case, it takes a longer sequence of unexpected shocks of the same sign, an unlikely event, to change membership. Thus, most of the time, equilibrium employment is stable, and unaffected by movements in the actual rate. But once in a while, a sequence of shocks pushes the equilibrium rate up or down, where it remains until another sequence dislodges it. Such infrequent changes appear to fit quite well with the empirical evidence on unemployment : unemployment seems indeed to be subject to infrequent changes in its mean level.

\section{Wage setting with some pressure from outsiders}

Assuming, as we have done above, that outsiders have no effect on wage setting, is too strong. First, new firms may hire the outsiders, and through competition in the goods market, force insiders in other firms to accept lower wages. To the extent however that new firms must pay fixed costs to set up production, they may find that, if the economy is depressed and unemployment is high, the size of the market they can enter does not make entry, even at low wages, an attractive option. Indeed, entry seems to occur mostly when unemployment is low, not when it is high.

Even if entry is not an issue, there are two other channels tinrough which unemployment may still affect the wage in existing firms. Higher unemployment means worse reeemployment prospects if laid off, and thus should lead the 

insilers to accept a lower wage and a higher probability of employment. Higher une ployment also implies that replacing the insiders in part or in toto by a new group of lower paid outsider workers is a more attractive option for the firm. Hiring outsiders against the will of the insiders may be costly, as insiders may well harass the outsiders; replacing the whole labor force may also be costly, because of the presence of specific human capital. But a large enough wage differential between the employed and the unemployed may ne:ertheless make it attractive and strengthen the hand of the firm in bargaining. 4

We can capture these effects by modifying equation (3) to read :

$$
\text { (3') } E n_{i} \cdot n_{i} *-b(\underline{n}-E n) ; b>0
$$

where $\underline{n}$ is the labor force and $\mathrm{En}$ is expected employment ${ }^{5}$, so that ( $\underline{n}-\mathrm{En}$ ) is expected unemployment. The stronger the effect of unemployment on wage set:ing, the larger the expected level of employment in firm $i$, the lower the nominal wage $w_{i}$. Let us assume that $n_{i} *=n_{i}(-1)$, the membership rule, which in the absence of pressure from outsiders, leads to a random walk in employment. Solving, as before, for the level of employment $\varepsilon$-ves :

(6) $n-\underline{n}=(1 /(1+b))(n(-1)-\underline{n})+(m-E m)$.

Employwent now follows a first order process around the level of the labor force. Thus, if the labor force evolves slowly over time, unemployment also follows apfroximaiely a first order autoregression. The degree of persistence is $a$ function of $b$. If $b$ is equal to zero, employment follows $a$ random walk. As b increases however, the degree of persistence decreases. After

4 The implicaticus of the ability of insiders to cooperate or harass outsiders has been explored by Lindbeck and Snower (1986), under the assumption of Nash bargaining between insiders and outsiders.

5 Actual employment is not known at the time of bargaining. 

sn adverse shock for example, actual unemployment increases, and so does equilibrium unemployment ; in the absence of subsequent surprises, unemployment eventually returns to a given value. But, during the transition, short run equilibrium unemployment is high.

If we look at richer membership rules, the results parallel those of the previous section. If it takes time to lose or acquire membership, only long sequence of shocks of the same sign will change equilibrium unemployment. Once it has changed however, it will only slowly (if b is small) go back to its initial value.

\section{Unemplovment Duration and the Wage Setting Process}

The first model we presented assumed that the unemployed had no effect on wage setiing while the model of the previous section assumed that all the Lnemployed exerted some downward pressure on the wage. A plausible intermediate pesition is that only the short term unemployed who have worked recently exert

downward pressure on wages. Empirical results by Layard and Nickell (1986), and Nickell (1986), suggest that this is indeed the case. Running a variety of wage equatiors, they conclude that most if not all of the pressure on wages comes in tire IK from those unemployed one year or less. There is little noticeable E: Eect of the long term unemployed on wages.

There are a number of complezentary explanations for why the long term Wuemployed might exert less influence on wage setting than those who have been out of work only briefly. Most obviously, skills may atrophy with protracted uremployment to the point where workers productivity falls below their reservation wage, or the wage which insider workers allow firms to offer. 

There is however little empirical evidence from either historical or microeconomic data to support this possibility. An alternative possibility is that workers' reservation wage or search intensity may decline as their unemployment spell continues. This may be because they adjust to a lower standard of living, become addicted to living on unemployment insurance benefits, or become discouraged about the prospects for reemployment. This effect and the insider effects discussed above are mutually reinforcing. Insider effects imply that a worker is less likely to be reemployed as his spell of unemployment lengthens. The discouragement of the long term unemployed in turn strengthens the hand of insiders in wage se:ting. 6

Assuming initially that short term unemployment is rougily equal to the change in unemployment, (we return below to the appropriateness of this assimption) equation ( $\left.3^{\prime}\right)$ may be modified to read:

(3") $E n_{i}-n_{i} *=b(n(-1)-E n)$

Thus, we assume that wage pressure from the outsiders depends not on total unemployment, but on (expected) short term unemployment. Assuming that the membership rule for insiders is still $n_{i} *-n_{i}(-1)$, and solving for agsregate emplcyment gives :

(7) $n=n(-1)+(m-E m)$

We recover our initial result that employment follows a :-andom walk. This is now the result of both the behavior of insiders, and the fact that only the short term unemployed put pressure on wages.

This full persistence result is however too strong. The cynamic relation

6 Another possibility is that the long term unemployed exert less pressure on wages because employers treat protracted unemployment as an adverse signal. Rational employers will however revise upwards their assessment of the ability of the long term unemployed when macroeconomic developments beyord the control of any single worker increase long term unemployment. 

between short term and total unemployment is in fact a complex dynamic relation, where the level of short term unemployment depends both on changes in and the level of unemployment. An increase in the flow into unemployment initially sharply increases the fraction of short term unemployment, but may eventually be associated with a decrease in this fraction as total unemployment rises. 7 Even taking account of these complications, the general result remains that if the long term unemployed exert little or no pressure on wages, an increase in long term unemployment increases equilibrium unemployment for some time. Like the insider model, this implies that short sequences of shocks will have little effect on equilibrium unemployment, while long sequences will increase equilibrium unemployment for some time.

\section{Conclusion}

While they appear to be able to explain the broad macroeconemic facts of the $80^{\prime} \mathrm{s}$, hysteresis theories are still in their infancy and need further development and testing. At the theoretical level, it would be desirable to consider more complex bargaining structures than those treated so far. An obvious direction for empirical research is the study of wage behavior at a disaggregated level. If insider and membership considerations are important, wages at the sectoral level should depend for example largely on sectoral concitions as well as o:. the previous history of employment in the sector.

Even given our current knowledge, hysteresis models point to different policy choices from those implied by models in which equilibrium unemployment is not affected by actual unemployment. ${ }^{8}$ They suggest that left to themselves,

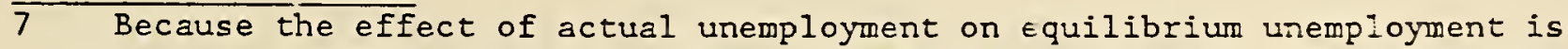
not permanent in this case, Layard and Nickell have privatel: o:jected to the Lise of the word hysteresis to describe their theory.

8 We elaborate on this point both in Blanchard and Summers (1986a) and (1986b). 

European economies may remain at high unemployment for the foreseable future. Regardless of the source of shocks which have led to increased unemployment, they imply that policies to decrease the actual rate, if successful, would probab!y also lead to decreases in the equilibrium rate. Finally, they suggest that, to succeed, policies must be aimed at reenfranchising the unemployed, in particular the long term unemployed.

Layarl and Nickell (2986) also draw implications of their analysis for policy. 



\section{References}

Blanchard, O. and L. Summezs, (1986a), "Hysteresis and the European Unemployment Pioblem", in NEER Mecroeconomics Annual, Vol 1, Stanley Fischer ed, MIT Press, September

Blanchard, C. and L. Summers (1986b), "Fiscal Policy, Real Wages and European Unemployment", mimeo Harvard, June

Gottfries, N. and H. Horn, (1986), "Wage Formation and the Persistence of Unemployment", WP 347, Institute for International Economic Studies, Stockholm

Gregory, R. ,(1986), "Wages Policy and Unemployment in Australia", Forthcoming in special issue cn unemployment, Economica

Layart, L. and S. Nickell, (1986), "The Performance of the British Labour Ma: iet", paper presented at the Chelwood Gate Conference on the British Economy, May

Lindbeck, A. and D. Snower, (1984), "Involuntary Unemployment as an Insider-Outsider Dilemna", Seminar Paper no 282, Institute for International Economic Studies, Stockholm

Iindbeck, A. and D. Snower, (1985), "Wage Setting, Unemployment and insider-Outsider Relations", Working Paper no 344, Institute for International Economic Studies, Stockholm

Lindbeck, $\dot{f}$. and D. Snower, (1986), "Cooperation, Harassment and Irvolur:ary Unemployment", Working Eaper 321, Institute for International Economic Studies, Stockolm Oxford.

Nickell, S., (1986), "Why is Wage Inflation in Britain so High ?", mimeo,

Phelps, E. (1972) Inflation Theorv and Unemployment Policy, Norton

Sachs, J. "High Unemployment in Europe: Diagnosis and Policy Implicarions" Harvard mimeo 
